man. In my own garden, where I have had standing always from ten to fifty swartins, and over which I thought I was watching with almost a fatherly affection, I have learned how utterly selfish I was in looking forward to autumn, whien, by the destruction of the industrious and unselfish bees, I could lay in for my own consumption what they had so laboriottsly gathered in the summer to sustain each other through the winter. I learned, from their unselfishness, to divide with them, always leaving enough to sustain the colony till the spring should again bring the flowers.

I think, too, that both Sir John Lubbock and your correspondent are mistaken as to the object of beating pans, sounding horns, and making other hideous noises in hiving bees. The object is not, as Sir John intimates, originally to drive away evil spirits, or to assert ownership, as indicated by Mr. Renshaw. It is simply, as everyone knows who ever thumped on a pan, sounded a horn, or yelled through a speaking trumpet on such an occasion, to drown the voice of the queen or guides who are to conduct the swarm to the new home which members of the community who had been sent out, as the Israelites sent forward Joshua and others, had found for them.

Mr. Renshaw's law is probably good, but does not apply in the case trying.

City of Williamsport, Pa., U.S.

\section{Flowering of the Hazel}

IT was with great interest that I read the communication from F. D. Wetterhan, in NATURE, vol. xi. p. 507. But I cannot help expressing quite a different opinion as to the bearing of the interesting fact that proterandrous and proterogynous individuals are to be found in the same locality. From the structure of the flowers and from insects never visiting the stigmas, I am convinced that the hazel is a strictly anemophilous plant; that the red colour of its stigmas is solely an effect of chemical processes connected with the development of the female flowers to maturity, just in the same manner as in the female flowers of the larch-tree and some other Coniferæ; and that likewise the coexistence of proterandrous and proterogynous individuals in the hazel relates solely to the influence of the wind, and not at all to the agency of insects.

Whilst in Primula, Pulmonaria, and many other entomophilous plants, so admirably treated of by Charles Darwin, two kinds of individuals, viz., long-styled and short-styled ones, have originated from the positions of the anthers and the stigmas diverging in different individuals in opposite directions-among the anemophilous plants in Fuglans regia * and Corylus avellana, among the entomophlous ones in Syringa vulgaris $t^{2}$ and Veronica spicata, + two kinds of individuals, namely, proterandrous and proterogynous ones, have originated from the periods of development of the anthers and stigmas diverging in different individuals in opposite directions. The effect in the two contrivances has been the same, cross-fertilisation not only between different flowers, but also between different branches, having become indispensable.

In dimorphous species, this cross-fertilisation, as is known, is effected by the visiting insects touching with the same part of their body the anthers of the long-styled and the stigmas of the shortstyled form; and with some other part of their body the anthers of the short-styled and the stigmas of the long-styled form. This kind of intercrossing can apparently never be effected by the wind; whence long-styled and short-styled (dimorphous) species are never to be found among anemophilous plants. But in these the coexistence of proterandrous and proterogynous individuals produces the same effect, the pollen-grains of the proterandrous individuals, of course, being transported by the wind only to the stigmas of the proterogynous ones, and vice vers $\hat{\text {. }}$.

Lippstadt, May I HERMANN MÜLLER

\section{Variable (?) Star in Sextans}

THE following may be of interest to the readers of your Astronomical Column :-

About $2 \frac{1}{2}^{\circ}$ north of, and a little preceding $\lambda$ Hydra (4 mag.), is a star marked 5th mag. in Harding's large Atlas Novut Calestis (1822). This is now invisible to the naked eye, and of about mag. 7. It is 19662 in I.alande's Catalogue, in which it is rated at $4 \frac{1}{2}$ mag. It seems difficult to understand how excellent * Delpino, "Ulteriori osservazioni," Parte II. fasc. ii. p. 337.

$\ddagger$ Ibid.p. 285 . observers like Harding and Lalande could have made a mistake of 2 magnitudes in the estimation of a star's brightness, particularly as it is closely preceded by a $7 \frac{1}{2} \mathrm{mag}$. star (Lalande, 19646). So that probably this star has faded since 1822 . Its position for the beginning of the present year is in R.A. 9h. $57 \mathrm{~m} .30^{\circ} 46 \mathrm{~s}$, and N.P.D. $98^{\circ} 58^{\prime} \mathrm{o}^{\prime \prime} 42$.

Punjab, India, April 3

J. E. GORE

\section{Equilibrium in Gases}

Mr. Nichor.s, in NATURE, vol. xi. p. 486, advances the opinion that in a vertical column of gas at rest the temperature does not tend, as generally believed, to become equal throughout, but that such a column is in a state of thermal equilibrium when the temperature diminishes at the rate of $I^{\circ}$ centigrade for every 233 feet of ascent (or $\mathrm{I}^{\circ} \mathrm{Fahr}$. for every I29 feet). This is a question of thermo-dynamics, and I am not mathematician enough to offer any opinion on it from the theoretical point of view, but it seems inconsistent with well-known meteorological facts. Were it true, there would be, as $\mathrm{Mr}$. Nichols points out, a constantly renewed tendency for the lower strata to flow upwards in consequence of their higher temperature and consequent relative expansion. Such a tendency is no doubt very common, but Mr. Nichols's theory would require it to be universal, and it does not appear to exist in the absence of direct solar heating. Cumulus cloud is an infallible proof of the presence of ascending columns of air, and according to the report of the Austrian Polar Expedition in NATURx, vol. xi. p. 415, cumulus is never seen in the Arctic winter; and I have somewhere read the same respecting the Siberian winter. The true cuuse of the accumulation of heat in the lower atmospheric strata, to which upward currents and the formation of cumulus is due, is, I have no doubt, that ustally assigned--namely, that the atmosphere is more pervious to the heat of the sun thun to heat radiated back from the earth; so that, as I think Tyndall expresses it, the sun's heat is caught as in a trap.

Old Forge, Dunmurry, Co. Antrim, April 30

\section{Curious Phenomenon of Light}

RowiNG on Loch Lomond recently, above' Luss, there were seen to the north-west; at an apparent distance of about roo yards, two bright lines of prismatic light, $60^{\circ}$ apart and on the level of the water. Their length seemed to equal the breadth of a rainbow. Their violet ends were towards each other, and were joined by a line of dull white light, to the middle of which the sun and the spectator were at right angles. Standing in the boat, the colour and brilliancy were lost, and only a diffuse white light was visible. The time was IO A.M. The sun was hot, the sky cloudless, the air hazy and still, and the loch a mirror. This apparition fled before our approach for some minutes, till dispelled by a slight breeze, which rippled the water.

Luss

WM. M'LAURIN

\section{Destruction of Flowers by Birds}

I ENCLOSE some flowers of the common blackthorn, that I suppose to have been snipped off by birds. The bushes were growing in the outskirts of a wood, in a very sequestered situation (near Dunstable). The upper branches appeared to have chiefly suffered. The grass below was quite conspicuously starred with the fallen blossoms. I can hardly think that human intervention had anything to do with it.

Hatfield, May 5

[In the accompanying specimens the limb of the calyx (carrying the stamens and petals) had been neatly cut away from the tube.]

\section{OUR ASTRONOMICAL COLUMN}

Orbits of Binary StaRs.-Dr. Doberck, of Colonel Cooper's Observatory, Markree, Co. Sligo, has published the results of a new investigation of the elements of the revolving double star $\sigma$ Coronæe Borealis, in which measures to the end of 1872 are included. The period of revolution is increased to 843 years, which is longer than any yet assigned to this star. Dr. Doberclk's comparison of his orbit with the measures of the late Rev. W. R. Dawes affords another proof of the remarkable excellence of that astronomer's observations, particularly in the last 